\title{
Site-wise Mercury Levels in Ulhas River Estuary and Thane Creek near Mumbai, India and its Relation to Water Parameters
}

\author{
J.S. Menon* and S.V. Mahajan \\ B.N. Bandodkar College of Science, Chendani-Koliwada, Thane (West), Mumbai-400601, India \\ *E-mail: jaisat@hotmail.com
}

Received: 11.06.2010, Accepted: 20.10.2010

\begin{abstract}
Ulhas river estuary $\left(73^{\circ} 14^{\prime} \mathrm{E}, 19^{\circ} 14^{\prime} \mathrm{N}\right.$ to $\left.72^{\circ} 54^{\prime} \mathrm{E}, 19^{\circ} 17^{\prime} \mathrm{N}\right)$ and Thane creek $\left(72^{\circ} 55^{\prime} \mathrm{E}\right.$, $19^{\circ} \mathrm{N}$ to $73^{\circ} \mathrm{E}, 19^{\circ} 15^{\prime} \mathrm{N}$ ) near Mumbai, India are highly polluted owing to the heavy load of industrial pollutants and sewage discharge. The traditional fisher-folk living along the banks of Ulhas river estuary and Thane Creek rely on these contaminated fish for their daily sustenance, thereby being exposed to heavy mercury pollution for several years. However, little attention has been given to the levels of mercury in water, its intake and exposure to those populations. In the present study, mercury levels in the waters of Ulhas river estuary and Thane creek has been analysed and its relation with other physicochemical parameters have been studied. Mercury level was maximum in Wehele station and Alimgarh station with an average of $8.57 \mathrm{ng} / \mathrm{ml}$ and minimum at Diwe-Kewni station with $2.6 \mathrm{ng} / \mathrm{ml}$. Vittawa and Airoli stations along Thane creek showed moderate levels with an average of $5.71 \mathrm{ng} / \mathrm{ml}$. The reference site, Khadavli had $\mathrm{Hg}$ below the level of detection in the water samples. Study on Hg levels in water showed proximity to the source of discharge to be the prime factor for its elevated levels. Mercury in water depicted positive correlations with temperature and BOD and negative correlations with $\mathrm{pH}$, salinity, hardness and DO.
\end{abstract}

Key words: Thane creek, Ulhas river estuary, mercury levels

\section{Introduction}

Thane creek $\left(73^{\circ} 14^{\prime} \mathrm{E}, 19^{\circ} 14^{\prime} \mathrm{N}-72^{\circ} 54^{\prime} \mathrm{E}\right.$, $\left.19^{\circ} 17^{\prime} \mathrm{N}\right)$ and Ulhas river estuary $\left(72^{\circ} 55^{\prime} \mathrm{E}\right.$, $\left.19^{\circ} \mathrm{N}-73^{\circ} \mathrm{E}, \quad 19^{\circ} 15^{\prime} \mathrm{N}\right), \quad$ located near Mumbai, India, receive tones of industrial effluents from the different industries and domestic sewage from the residential complexes, located along their banks. The aquatic organisms are highly influenced by pollutants present in water and also by its physico-chemical parameters which include $\mathrm{pH}$, temperature, salinity, hardness, dissolved oxygen (DO) and biochemical oxygen demand (BOD). Mercury $(\mathrm{Hg})$ is one of the most hazardous environmental pollutants due to its toxicity and its accumulation in aquatic organisms (Agah et al., 2007). According to Dallinger et al. (1987), the chemistry of water influences $\mathrm{Hg}$ metabolism both in marine and limnetic environments. Factors such as $\mathrm{pH}$, hardness and salinity are reported to be crucial in this respect.

A few studies conducted on $\mathrm{Hg}$ concentrations in water, sediments and fish of Ulhas river estuary and Thane creek in the past have confined either to only one 
location or a part of the estuary or creek (Tejam and Haldar, 1975; Zingde and Desai, 1981; Hasan, 1984; Baig, 1988). Hence, it is obligatory to analyse the present concentration of $\mathrm{Hg}$ in water along Thane creek and Ulhas river Estuary and also study its relation to other influential water parameters.

The present work aims to study $\mathrm{Hg}$ concentration in the waters from different sites along Ulhas river estuary and Thane creek. An attempt has also been made to relate levels of $\mathrm{Hg}$ with influential water parameters, which is first of its kind in the study areas. This study also helps to assess the pollution status of the study areas and the probable risk posed to the populations consuming fish from Ulhas river estuary and Thane creek.

\section{Methodology}

Station wise analysis of water parameters was conducted during the pre-monsoon season of May 2005. Water samples were collected from the vicinity of the bank near the High level water mark. The sites of water sampling are shown in the figure 1.

\section{Sampling stations}

Station 1. Khadavli (Reference site): This station located along Khadavli village $\left(19^{\circ} 21^{\prime} \mathrm{N}\right.$ and $\left.73^{\circ} 13^{\prime} \mathrm{E}\right)$ is $15 \mathrm{~km}$ upstream of Ulhas river estuary on the southern bank of the river Bhatsai, a tributary of river Ulhas. It is a non polluted area and the water has been declared safe for drinking purposes. The entire stretch of river has been classified as A-one class (MPCB, 2004-2005).

Station 2. Wehele: This station is located near Wehele village $\left(19^{\circ} 14^{\prime} \mathrm{N}\right.$ and $\left.73^{\circ} 03^{\prime} \mathrm{E}\right)$ on the northern bank of Ulhas river estuary.
This site is located $15 \mathrm{~km}$ downstream of Vadavli village where the estuarine zone of Ulhas river begins. The two chlor-alkali plants, one at Mohane and the other at Shahad are located upstream of this site. On the opposite bank of this site lies the heavily polluted, industrialised and overcrowded city of Dombivli (Lokhande et al., 2001). The two effluent discharges of MIDC (Maharashtra Industrial Development Corporation) Phase I and II regions of Dombivli join Ulhas river estuary at this bank. In addition, this site receives the polluted water from the upstream industrial zones of Ulhasnagar, Badlapur, Ambarnath, Bhiwandi and Shahad-Ambivli (Hasan, 1984).

Station 3. Alimgarh: This station is situated near Alimgarh village $\left(19^{\circ} 12^{\prime} \mathrm{N}\right.$ and $\left.73^{\circ} 02^{\prime} \mathrm{E}\right)$ on the northern banks of Ulhas river estuary, $7 \mathrm{~km}$ downstream of station 2 . This site is also under considerable environmental stress due to the sewage outlet from Mumbra creek as well as the solid waste dumping on the opposite bank where the urbanized overcrowded town of Mumbra is located. Moreover, discharges from highly polluted MIDC Phase II region of Dombivli effluent canal is just $4 \mathrm{~km}$ upstream of this site. Inflow of polluted upstream water plus sewage and solid waste at this site together make it a highly polluted zone.

Station 4. Diwe-Kewni: This station is located near the twin villages of DiweKewni $\left(19^{\circ} 16^{\prime} \mathrm{N}\right.$ and $\left.73^{\circ} \mathrm{E}\right)$, on the northern bank of Ulhas river estuary. At this site, Kamwadi river joins Ulhas river estuary. It is $10 \mathrm{~km}$ downstream of station 4 and $10 \mathrm{~km}$ upstream of Vasai creek where Ulhas river estuary meets Arabian Sea. It is 


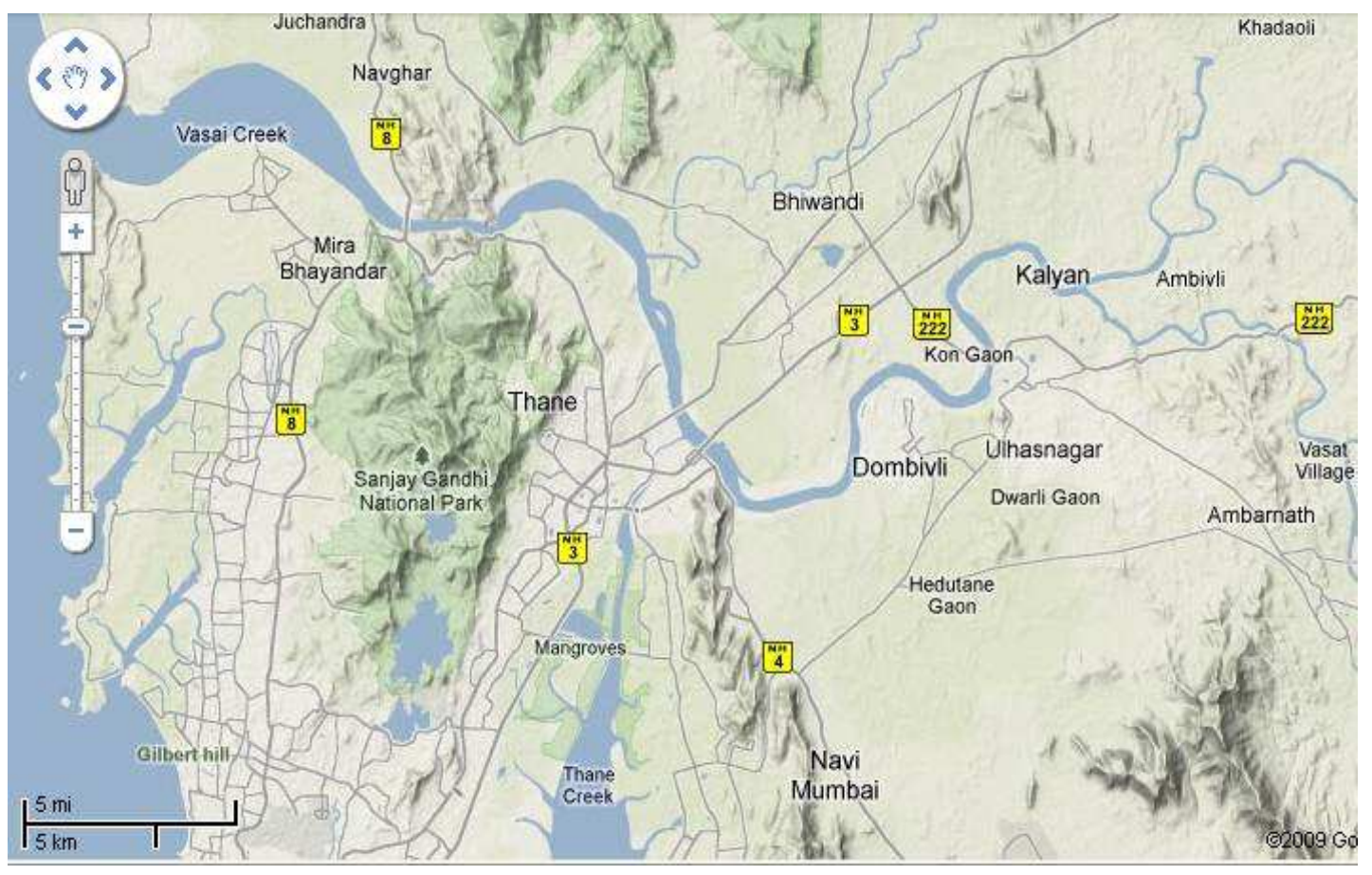

Figure 1. Map of Ulhas River Estuary, Thane creek and sampling sites.

comparatively less polluted, except for occasional sewage brought by Kamwadi river from the township of Bhiwandi (Mercury in India, Environmental Health Aspects, www.toxicslink.org).

Station 5. Vittawa: This station is located 2 $\mathrm{km}$ downstream of Thane railway bridge on the eastern bank of Thane creek, near Vittawa village $\left(19^{\circ} 11^{\prime} \mathrm{N}\right.$ and $\left.72^{\circ} 59^{\prime} \mathrm{E}\right)$. This site is under tremendous pollution stress due to the domestic sewage released from Thane city and Mumbai suburbs on the west bank, Trans-Thane Creek (TTC) Industrial area on the east bank and also other anthropogenic activities like road and bridge constructions, land reclamation etc.
Station 6. Airoli: It is located on the east bank of Thane creek near Airoli village $\left(19^{\circ} 8^{\prime} \mathrm{N}\right.$ and $\left.72^{\circ} 59^{\prime} \mathrm{E}\right), 4 \mathrm{kms}$ downstream of Vittawa. This station receives effluents from the residential and industrial areas of Airoli region. There are many untreated sewage discharges in this region. (Quadros 2001; Athalye and Goldin, 2002; Borkar, 2004). A chlor-alkali plant is situated in the vicinity of this site between the villages, Vittawa and Airoli.

\section{Sample collection and analysis of physico- chemical parameters as well as $\mathrm{Hg}$ levels in water}

The collection, preservation and analysis of $\mathrm{Hg}$ concentration in the water samples were 
carried out as per standard methods (APHA, 1981). Estimation of other parameters like $\mathrm{pH}$, salinity, hardness, temperature, $\mathrm{DO}$ and BOD of the water samples were carried out in situ as per APHA (1981) methods. Prior to the analysis by Mercury Analyser MA 5804 (CVAAS), $\mathrm{SnCl}_{2}$ was added which acted as a reducing agent and released $\mathrm{Hg}$ vapours from the sample. The obtained results were then subjected to statistical analysis using Pearson's correlation in order to evaluate the relation between $\mathrm{Hg}$ levels and physico-chemical parameters.

\section{Results}

Station wise water sample analysis for $\mathrm{pH}$, temperature, salinity, hardness, DO, BOD and $\mathrm{Hg}$ levels have been presented in table 1. The correlation between environmental variables during pre-monsoon season has been presented in table 2 .

Cross-correlation analyses between pairs of environmental variables identified a number of significant positive and negative relationships (Correlation co-efficient $\mathrm{R}$ was found out at 5\% level of significance). The table showed $\mathrm{Hg}$ in water positively correlated to temperature and BOD and negatively correlated to DO, salinity, hardness and $\mathrm{pH}$. .

\section{Discussion}

Station wise study revealed that reference site; Khadavli (Station 1) of the present study showed $\mathrm{Hg}$ levels below detection limit. This was attributed to the nonpolluted status of the waters of river Bhatsai. The sites at riverine end of Ulhas river estuary (Stations 2 and 3) had higher levels of $\mathrm{Hg}$ concentration than the site at seaward end (Station 4). Srinivasan and Mahajan (1989) and Ram et al. (2003) have also documented decreasing levels of $\mathrm{Hg}$ in sediments from riverine end to seaward end of the same estuary. Various factors influence this decrease in concentration of mercury from riverine to seaward end which have been discussed below.

Proximity to sources of discharge was the principal factor which determined the concentration of mercury in water (Srinivasan and Mahajan, 1989). Contamination of water at the point source of discharge has been reported by many scientists (Hasan, 1984; Baig, 1988; Quadros, 2001).

In present study areas, chlor-alkali industries which released mercury were situated upstream of Ulhas river estuary between station 1 and station 2 at Shahad and Mohane (Mercury in India: Usages and Releases, www.toxicslink.org, Ram et al., 2003). The above units together produce roughly $85,000 \mathrm{t} / \mathrm{yr}$ of caustic soda and release about $48,000 \mathrm{~m}^{3} / \mathrm{d}$ of processed and $6000 \mathrm{~m}^{3} / \mathrm{d}$ of domestic effluents in the estuarine segment upstream of station 2 (Ram et al., 2003).

These units set-up during 1951-1964, manufactured caustic soda through Hg cell process until 1998-99 but since then they have been reported to be producing a bulk of the product through membrane cell technology. Hence, Ulhas estuary had been receiving the fluxes of $\mathrm{Hg}$ from chlor-alkali plants for over 45 years (Ram et al., 2003). Due to its persistent nature, $\mathrm{Hg}$ remains in the system for 20 years after its deposition (www.toxicslink.org). Although change in electrolytic process has largely eliminated the use of $\mathrm{Hg}$ in chlor-alkali plants, past emissions deposited in aquatic environment and those emanating from other sources continue to exhibit its distinct signature in water, sediment and biota of regions influenced by its fluxes. 


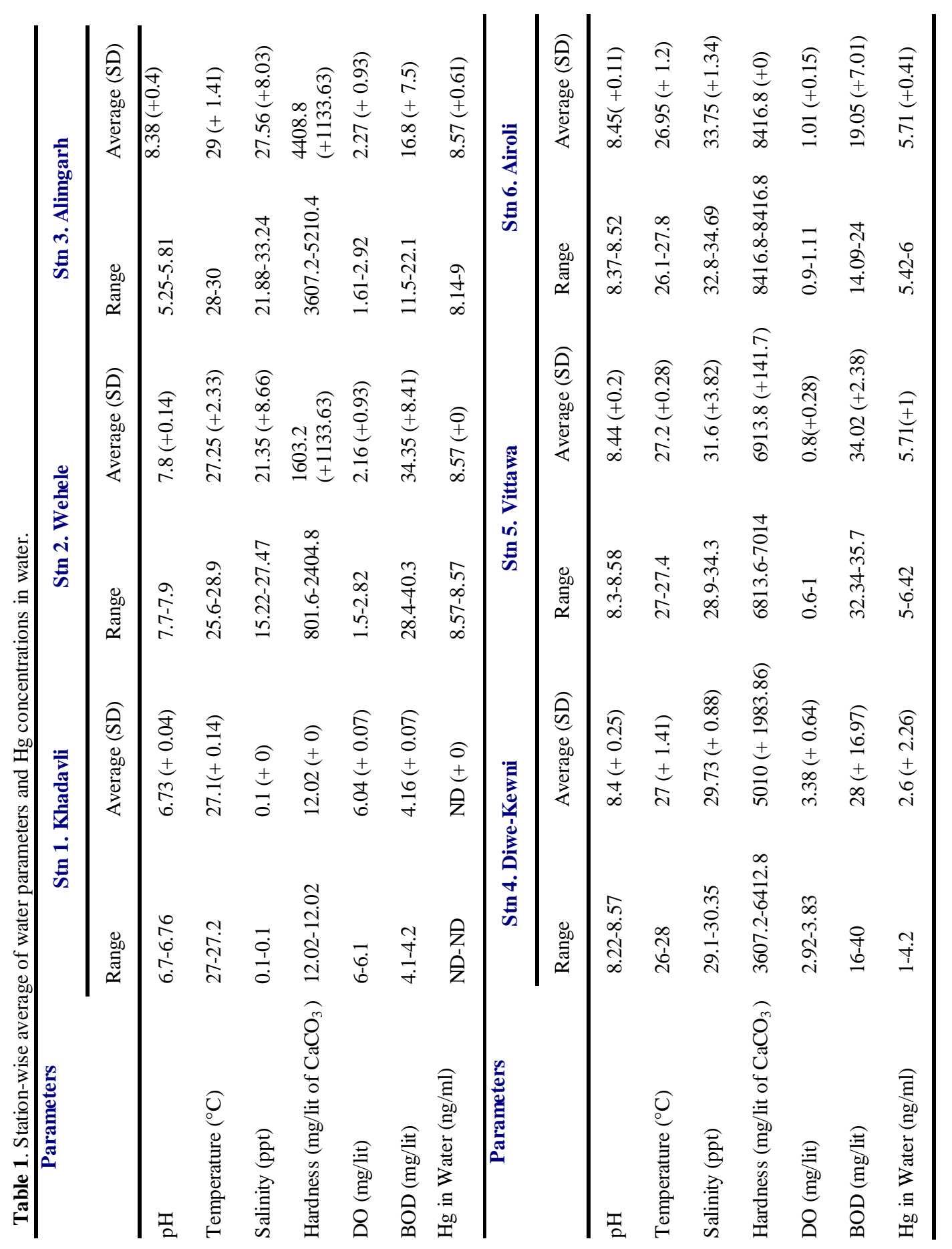


J.S Menon and S.V. Mahajan / Our Nature (2010) 8: 170-179

Table 2. Pearson's Correlation Coefficients between environmental variables.

\begin{tabular}{lccccccc}
\hline $\begin{array}{l}\text { Pre-monsoon } \\
(\mathbf{2 0 0 5})\end{array}$ & Hg in Water & Temperature & DO & BOD & Salinity & pH & Hardness \\
\hline Hg in Water & 1 & & & & & & \\
Temp & 0.267815118 & 1 & & & & & \\
DO & -0.139572418 & -0.065846857 & 1 & & & & \\
BOD & 0.076879048 & -0.592128532 & 0.06894 & 1 & & \\
Salinity & -0.400661278 & -0.577245568 & -0.2391 & 0.06639 & 1 & & \\
pH & -0.478659197 & 0.320736018 & -0.1941 & -0.4957 & 0.453683 & 1 & \\
Hardness & -0.350239418 & -0.377351273 & -0.4358 & -0.0302 & 0.826986 & 0.5877 & 1 \\
\hline
\end{tabular}

Particulate segments enriched with mercury get settled in sediments at point source upstream of the estuarine zone (Ram et al., 2003) Due to strong water currents, these segments are dispersed in the water column as suspended particulate matter (SPM). $\mathrm{Hg}$ is mainly transported in particulate matter because of its high adsorption capacity especially on to fine particles (clay) and stability of its carbon binders (Maurice-Bourgoin et al., 2000). SPM along with mercury is transported downstream into the upper estuarine stretch where it gets deposited. This made sediments remain confined to the inner estuary making it a major sink of mercury. Higher values of mercury in stations 2 and 3 of the present study can be attributed to the leaching of $\mathrm{Hg}$ from this sink.

However, towards the sea, the contaminated SPM transported downstream during ebb tide gets diluted by naturally occurring high SPM in the outer estuary and also gets distributed over a large area as the estuary widens in the seaward direction. This explains the significantly lower and decreasing levels of $\mathrm{Hg}$ in the outer estuary. Above reasoning holds good for low levels of $\mathrm{Hg}$ in water of Station 4 of the present study. Similar explanations have been put forth by Miller (1997) for the decrease in heavy metal concentration downstream of rivers.

Apart from chlor-alkali industries, fumes containing $\mathrm{Hg}$ released from medical waste incinerator located at Kalyan, which is in the vicinity of stations 2 and 3, travel through air and get dissolved in the waters of Ulhas river estuary either by atmospheric dissolution or through rainwater, thus adding to $\mathrm{Hg}$ levels in water. Atmospheric transport is an important vehicle for $\mathrm{Hg}$ distribution (Peterson et al., 2002). The untreated and partially treated sewage from highly populated cities of Kalyan, Dombivli, and Ulhasnagar and also heavy load of industrial effluents released from MIDC (Maharashtra Industrial Development Corporation) zones in the vicinity aggravate $\mathrm{Hg}$ levels in these areas.

Salinity and hardness come next in influencing mercury concentration in water. A negative correlation between mercury concentration and salinity (-0.4) and also between mercury concentration and hardness (-0.3502) was obtained in the present study. A negative correlation between metals in water and salinity was attributed to the sharp increase in salinity when sea water mixes with fresh water (Senthilnathan and Balasubramaniam, 1998). This results in precipitation and 
coagulation of colloidal clay particles and co-precipitation of metals with/or adsorption to particles and remove considerable amount of metals from the solution (Senthilnathan and Balasubramaniam, 1998). Increasing salinity also reduces methylation due to interference from chloride ions, so the relative quantity of methylation in marine water was lower than in fresh water (Moore and Ramamurthy, 1984). Similar relation between salinity and mercury in water was observed in Zuary estuary, Uppanar, Vellar and Kaduviyar estuaries of India (Senthilnathan and Balasubramaniam, 1998). In a similar way, hardness of water too has an inverse relationship with $\mathrm{Hg}$ levels in water. Hardness of water showed an increasing trend from station 1 to station 4 of Ulhas river estuary. Hardness generally reduces the inorganic chemicals in water (Hamelink et al., 1994). This could also be the probable reason for the decreasing trend in $\mathrm{Hg}$ in water from riverine to seaward end of the estuary.

Mercury concentration in water is also influenced by DO in water. A negative co-relation between $\mathrm{Hg}$ and $\mathrm{DO}$ in water has been obtained in the present study which indicate that the lesser the DO in water more is the mercury concentration. Sediment mercury showed inverse relationship to the variables of DO (MDEP, 1997).This is because ionic mercury once present in water is capable of forming a wide variety of complexes with organic matter which occurs in anaerobic conditions (WHO, 1976). So in the present study, it was observed that stations 2 and 3 with low DO have higher $\mathrm{Hg}$ levels than station 4. Similar observations have been recorded by Satpathy et al. (2008).
Other factors influencing mercury in water are $\mathrm{pH}$ and temperature (WHO, 1989). It is understood that acidic conditions accelerate the leaching of trace metals from soils, thus increasing mercury in water (WHO, 1990). Also precipitation of metals at sediment water interface is encouraged by high $\mathrm{pH}$ values. In estuarine environment, $\mathrm{pH}$ is of lesser importance as the system is well-buffered. Although variation in $\mathrm{pH}$ was not very significant among the stations, values of $\mathrm{pH}$ showed a slight increase towards seaward side of the estuary. Thus contribution of acidic conditions for elevating mercury levels in water to a certain extent in the riverine side was observed in the present study.

As far as Hg levels in Thane creek are concerned, it was observed that stations 5 and 6 located along Thane creek were also subjected to heavy pollution by untreated or partially treated industrial effluents released from Thane-Belapur Industrial belt on the eastern bank and industries in Mumbai on the western bank, and also domestic sewage from the heavily populated cities of Thane, Mulund and Navi-Mumbai areas. Fumes containing $\mathrm{Hg}$ from the waste incinerator at Airoli, dumping grounds at Chembur and thermal power plants at Tarapur and Chembur also travel through the air and finally get dissolved in the waters of Thane creek.

A chlor-alkali manufacturing unit is also located between stations 5 and 6 (www.toxicslink.org) of the present study areas which releases $\mathrm{Hg}$ in to Thane creek. Thane creek/Bombay Harbour receives at least 250 million litres/day of domestic waste water from some treatment plants and pumping stations on the western bank. Effluents from the major treatment plants 
located at Colaba and Ghatkopar gave mercury concentration ranging from 100 to $1200 \mathrm{ng} / \mathrm{l}$ with an average of $650 \mathrm{ng} / \mathrm{l}$ (Zingde and Desai, 1981). Discharge of $\mathrm{Hg}$ containing effluents in to Thane creek from chlor-alkali plants leading to fish kill has also been reported by Zingde and Desai (1981).

But it was observed that in comparison to $\mathrm{Hg}$ values of stations 2 and 3 of Ulhas river estuary, lower values were observed in Thane creek owing to several factors.

- Higher salinity and Hardness of Thane creek in comparison to Ulhas river estuary.

- Weak tidal currents and comparatively steady conditions of the creek (Quadros, 2001) lead to less turbulence of water and a greater rate of sedimentation of SPM. SPM adsorbs metals and other toxicants and settles to the sediments thereby reducing the toxins from the water.

- Another probable reason is the sand dredging activities in Ulhas river estuary along Kalyan, Dombivli and Mumbra. It is understood that larger load of suspended particulate matter takes place also due to erosion caused by agriculture, dredging and cutting of mangroves on the riverbanks (Rathod et al., 2002), which is a common sight along the upper stretches of Ulhas river estuary. This brings about re-suspension of the particles from the sediments to the water column and increase the SPM in water (Athalye and Goldin, 2002) Mercury adsorbed to this material (Roulet et al., 1998), get released to water (Roulet et al., 1998), thereby elevating $\mathrm{Hg}$ levels in these regions.
In the study carried out by Ram et al. (2003), on mercury concentrations in the sediments and water of Ulhas river estuary and upstream rivers, mercury levels of water were found in the range of 0.05 to $0.61 \mu \mathrm{g} / \mathrm{L}$ in the inner estuary which includes stations 2 and 3 of the present study. They used filtered water containing only dissolved $\mathrm{Hg}$ and no particulate $\mathrm{Hg}$. This reasoned for the low values obtained for mercury in water in the above studies. The particulate matter obtained after filtration of water in the same study by Ram et al. (2003) showed a high $\mathrm{Hg}$ concentration in the range 1.22 to 6.43 $\mu \mathrm{g} / \mathrm{g}$. This reveals the influence of SPM in the distribution of $\mathrm{Hg}$ in water.

A similar observation was also documented by Kehrig et al. (2002) in their studies on Brazilian estuary, Rio de Janeiro with dissolved $\mathrm{Hg}$ in the range of 0.5 to 3.2 $\mathrm{ng} / \mathrm{l}$ and high levels of particulate $\mathrm{Hg}$ in the range of 60.7 to $380 \mu \mathrm{g} / \mathrm{kg}$. Satpathy et al. (2008) also reported that unfiltered water contained dissolved and acid-leachable particles which increased $\mathrm{Hg}$ levels in water samples in comparison to filtered ones. Their studies revealed a range of $\mathrm{Hg}$ concentration from $1.5 \mathrm{ppb}$ to $50 \mathrm{ppb}$.

Dissolved Hg entered the fish through the gills (Dallinger et al., 1987) whereas inorganic $\mathrm{Hg}$ that get adsorbed to the SPM settles down (Kehrig et al., 2002), gets methylated and finally enter the foodchain, leading to the process of bioaccumulation (www. cleanestuary.org, 2006). Since the present study primarily focuses on bioaccumulation, it was important to estimate total $\mathrm{Hg}$ i.e., dissolved as well as acid-leachable $\mathrm{Hg}$ in water. According to Anil and Wagh (1988), while estimating total concentration of trace metal 
in water, dissolved concentration plus total particulate concentration of the metal should be taken into consideration.

The recommended levels of mercury in aquatic systems given by WHO (1989) include the following concentration ranges, which may be considered representative for dissolved mercury: Open ocean- 0.5-3 ng/l, Coastal sea water- $2-15 \mathrm{ng} / \mathrm{l}$, rivers and lakes-1-3 ng/l. Further, WHO (1989) points out that local variation from the recommended values are considerable, especially in coastal sea water and in lakes and rivers where mercury associated with suspended material may also contribute to the total load.

\section{Conclusion}

The study indicates persistence of $\mathrm{Hg}$ in waters of Thane creek and Ulhas river estuary. Proximity to the source of $\mathrm{Hg}$ discharge is observed to be the prime factor for the elevated levels of $\mathrm{Hg}$ in water. Higher levels of $\mathrm{Hg}$ are observed in waters of station 2 (Wehele) and station 3 (Alimgarh), located towards the riverine end of the estuary. Station 4 (Diwe-Kewni) located to the seaward end of the estuary show low levels of $\mathrm{Hg}$ in water. Lower levels are estimated in station 5 (Vittawa) and 6 (Airoli) of Thane creek in comparison to riverine end stations of Ulhas river estuary. $\mathrm{Hg}$ in water shows positive relationship with temperature and BOD while it is inversely proportional to $\mathrm{pH}$, salinity, hardness and DO.

\section{References}

Agah, H.M. Leermakers, M. Elskens, S.M.R. Fatemi and W. Baeyens 2007. Total mercury and methyl mercury concentrations in fish from the Persian Gulf and the Caspian Sea. Water
Air Soil Pollution. 10.1007/s11270-006-92810, Springer Science+ Business Media B.V.

Anil, A.C. and A.B. Wagh 1988. Accumulation of copper and zinc by Balanus amphitrite in a tropical estuary. Mar. Poll. Bull. 19(4): 177180.

APHA, AWWA and WPCF 1981. International standard methods for the examination of water and waste water, 15 th edition, American Public Health Association, American Water Works Assessment and Water Pollution Control Federation, Washington, D.C. pp. 270-430.

Athalye, R.P. and Q. Goldin 2002. Studies on the intertidal sediments of Thane creek and Ulhas river estuary. In Proc. National Seminar on Creeks, Estuaries and Mangroves- Pollution and Conservation. pp. 66-71.

Baig, M.M.N. 1988. Studies on the river Ulhas with reference to pollution in the vicinity of Shahad-Ambivli Industrial area and its effect on Punctius sophore (Ham.). University of Mumbai. (Ph.D. Thesis)

Borkar, M. 2004. Ecological study on mangrove ecosystem of Thane creek. University of Mumbai (Ph.D. Thesis)

Dallinger, R., F. Prosi, H. Segner and H. Back 1987. Contaminated food and uptake of heavy metals by fish: a review and a proposal for further research. Oecologia 73(1): 91-98.

Hamelink, J.L., P.F. Landrum, H.L. Bergman and W.H. Benson (Eds.) 1994. Bioavailability: physical, chemical and biological interactions. Lewis Publishers, Boca Raton.

Hasan, Q.R.A. 1984. Studies on pollution in Ulhas creek with reference to effluents from MIDC Kalyan-Bhiwandi and their effects on Mystus gulio. University of Mumbai. (Ph.D. Thesis)

Kehrig, H.A., O. Malm and I. Moreira 1998. Mercury in a widely consumed fish Micropogonias furnieri (Demarest, 1823) from four main Brazilian estuaries. Sci. Tot. Environ. 213: 263-271.

Lokhande, R.S., S. Vaidya and R. Bhave 2001. Physico-chemical studies of industrial effluents from the M.I.D.C. area of KalyanDombivil. In Aquatic Pollution and 
J.S Menon and S.V. Mahajan / Our Nature (2010) 8: 170-179

Toxicology (Ed. R.K. Trivedy), ABD Publishers, Jaipur, India. pp. 134-138.

Maurice-Bourgoin, L., I. Quiroga, J. Chincheros and P. Courau 2000. Mercury distribution in waters and fishes of the upper Madeira rivers and mercury exposure in riparian Amazonian populations. Sci. Tot. Environ. 260(1-3): 7386.

MDEP (Massachusetts Department of Environmental Protection) 1997. Fish mercury distribution in Massachusetts lakes. Final report. 64 p. www.mass.gov

Mercury in India- Environmental and health aspects, Chapter 2. www. toxicslink.org.

Mercury in India- Usages and releases. www.toxicslink.org.

Miller, J.R. 1997. The role of fluvial geomorphic processes in the transport and storage of heavy metals from mine sites. J. Geochem. Explor. Special Issue 58: 101-118.

Moore, J. and S. Ramamurthy 1984. Heavy metals in natural waters. Springer Verlag, New York.

MPCB (Maharashtra Pollution Control Board) 20042005. Environmental status report of Kalyan region. pp. 1-44. http://mpcb.mah.nic.in.

Peterson, S.A., A.T. Hertility, R.M. Huges, K.L. Motter and J.M. Robbins 2002. Level and extent of mercury contamination in Oregon, USA, Iotic fish. Environ. Toxicol. Chem. 21(10): 2157-2164.

Quadros, G., M. Vidya, V. Ullal, K.S. Gokhale and R.P. Athalye 2001. Status of water quality of Thane creek. Ecol. Env. Cons. 7(3): 235-240.

Ram, A., M.A. Rokade, D.V. Borole and M.D. Zingde 2003. Mercury in sediments of Ulhas estuary. Mar. Poll. Bull. 46: 846-857.

Rathod, S.D., N.N. Patil, G. Quadros and R.P. Athalye 2002. Qualitative study of finfish and shellfish fauna of Thane creek and Ulhas river Estuary. In Proc. of the National Seminar on
Creeks, Estuaries and Mangroves- Pollution and Conservation. pp. 135-141.

Roulet, M., M. Lucotte and R. Canuel 1998. Distribution and partition of mercury in waters of the Tapajos river basin, Brazilian Amazon. Sci. Tot. Environ. 213: 203-211.

Satpathy, K.K., S. Sarguru and U. Natesan 2008. Seasonal variations in mercury concentration in the coastal waters of Kalpakkam, Southeast coast of India. Curr. Sci. 95(3): 374-381.

Senthilnathan and Balasubramaniam 1998. Heavy metal concentration in oyster Crassastrea madrasensis (Bivalvia/Arisomyaria) from Uppanar, Vellar and Kaduviar estuaries of south-east coast of India. Ind. J. Marine Sciences 27: 211-216.

Srinivasan, M. and B.A. Mahajan 1989. Mercury pollution in an estuarine region and its effect on a coastal population. Intn. J. Environ. Stud. 35(1-2): 63-69.

Tejam, B.M. and B.C. Haldar 1975. Preliminary survey of mercury in fish from Bombay and Thane environment. Ind. J. Environ. Health 17(1): 9-16.

WHO, Environmental Health Criteria 1, Mercury 1976. Environmental programme and WHO, Geneva. pp. 5-131.

WHO, Environmental Health Criteria, 101, MethylMercury 1990. International programme on chemical safety, Geneva.

WHO, Environmental Health Criteria, 86, MercuryEnvironmental aspects 1989. International programme on chemical safety, Geneva. www.inchem.org/documents/ehc/ehc/ehc086. htm.

www.cleanestuary.org/publications/files/CEP_hg_CM Jan 2006, Conceptual model of mercury for CEP.

Zingde, M.D. and B.N. Desai 1981. Mercury in Thana creek, Bombay harbour. Mar. Poll. Bull. 12(7): 237-241. 